\title{
Konlk RELASI DUA TANDA DALAM KARYA SENI LUKIS
}

Jurnal Seni dan Desain

Volume 1, Nomor 1

Juli 2019,

(61-68)

\section{Novriko Darma}

Universitas Negeri Padang

e-mail : novriko_d@yahoo.com

\begin{abstract}
ABSTRAK
Mengeksplorasi kehidupan pemimpin dengan metafor payung, dalam kehidupan sehari-hari ke dalam karya lukis kontemporer. Payung disini berkaitan dengan gaya kepemimpinan, pemerintaan, dan politik, adapun payung tersebut dimetaforkan ke dalam kepemimpinan. Pemimpin disaat ini banyak yang menyalahgunakan kekuasaanya sehingga seorang pemimpin mampu melakukan apapun yang diinginkan bahkan melakukan tindakan criminal dan korupsi. Pembuatan karya akhir ini bertujuan memvisualisasikan relasi dua tanda dalam karya seni lukis, karya yang dihasilkan: Time is Reversed, The Doctrine of the leader, No Longer Body Size, Growth is Slow, krakter Pemimpin, Kong kali kong.

Kata kunci: Lukis, Relasi, Tanda
\end{abstract}

\section{ABSTRACT}

Explore the life of leaders with umbrella metaphors, in everyday life into contemporary painting. Umbrella here relates to the style of leadership, governance, and politics, while the umbrella is dimetaforkan into leadership. Leaders at this time many who abuse his power so a leader is able to do whatever is desired even to commit criminal acts and corruption. The making of this final work makes it easy to visualize the relation of the two marks in the work of art, the work produced: Time Reversed, Leader's Teachings, No Longer Body Size, Slow Growth, Leader krakter, Kong kali kong.

Keyword: Painting, Relation, Signs

\section{PENDAHULUAN}

Manusia merupakan khalifah di muka bumi ini, diciptakan oleh Allah dengan berbagai kelebihan dan kesempurnaan yang menyertainya. Ia dibekali akal, pikiran dan juga hawa nafsu sebagai pelengkapnya. Ia telah diberikan berbagai fasilitas di muka bumi sebagai alat pemenuhan kebutuhan manusia. Semua yang ia butuhkan telah terhampar di alam semesta, manusia hanya perlu mengelolanya saja. Dalam kehidupan sosial manusia butuh seorang pemimpin untuk melindungi rakyatnya. Pemimpin adalah seseorang yang memiliki kemampuan mengarahkan bawahannya untuk mencapai tujuannya. Tapi, sebagian pemimpin memiliki kekuasaan hanya untuk melindungi dirinya sendiri.

Payung berbentuk setengah bulatan, bagian tengahnya adalah tangkai pegangan dan dapat dilipat. Setiap sisi payung mempunyai rangka yang berfungi untuk memperkuat payung. Payung juga memiliki warna yang bermacam dan bentuk yang unik. Payung alat pelindung badan supaya tidak terkena panas matahari atau hujan.

Objek yang ingin diangkat yaitu payung dalam karya lukis kontemporer, yang menyimbolkan seorang pemimpin. Karya kontemporer merupakan karya yang secara tematik merefleksikan situasi waktu yang sedang di lalui. Seni kontemporer juga merupakan karya yang secara tematik merefleksikan situasi waktu yang sedang terjadi, misalnya kekacauan dan masalah sosial dan bentuk karyanya pun tidak terikat oleh zaman dahulu, bisa saja bentuk karyanya melebihi ukuran sebenarnya. Berdasarkan penjelasan di atas membuat saya memilih lukisan kontemporer karena bentuknya tidak terikat dengan ukuran asli. Menjelaskan situasi waktu yang sedang dilalui dan lebih mengedepankan aspek konseptual dari pada aspek bentuk (estetik).

Bertitik tolak dari latar belakang di atas, memvisualkan ide dan gagasan untuk karya akhir ini dengan judul Relasi dua Tanda dalam Karya Seni Lukis. Penciptaan karya ini saya merujuk karya yang dibuat seniman-seniman besar tanpa meniru persis karya mereka. Seniman rujukan yang menjadi panduan dalam berkarya adalah Made Wiguna Valasara yang merupakan seniman yang memiliki corak kontemporer serta karya-karya seorang seniman besar Tombly. Hal itu disebabkan karena karya-karyanya memiliki kedekatan secara visual dengan karya saya sendiri.

Banyak ilmuwan yang mendefinisikan pemimpin dalam pengertian seseorang yang memiliki kemampuan untuk mengarahkan kelompoknya menuju cita-cita yang diinginkan. 
Sedangkan yang dimaksud kepemimpinan adalah aktifitas mempengaruhi orang-orang demi mencapai cita-cita yang diinginkan Taniredja (Taniredja, 2014, p. 1)

Dalam KBBI (1989:656) Payung adalah alat pelindung badan supaya jangan kena panas matahari atau kena hujan, biasanya dibuat dari kain atau kertas diberi bertangkai dan dapat dilipatlipat, dan juga dipakai sebagai tanda kebesaran.

Menurut Anggia (Anggia \& Fredy, 2006, p. 5) Fungsi utama payung pada masa lampau adalah untuk berlindung dari panas matahari, sehingga payung awalnya dinamai 'parasol' yang berarti melindungi matahari. Selain berfungsi sebagai penahan hujan dan matahari, payung menjadi salah satu gaya atau aksesoris utama para wanita, terutama di daerah Eropa.

Relasi makna adalah hubungan kebermaknaan antara sebuah kata atau satuan bahasa lainnya dengan kata atau satuan bahasa lainnya. Hubungan kebermaknaan mungkin menyangkut hal kesamaan makna, kebalikan makna, kegandaan makna, ketercakupan makna dan sebagainya.

Menurut Sudaryanto, (1994: 15) dalam buku (Budiman, 2011, p. 69) bahwa tanda-tanda, bahkan tanda-tanda kebahasaan sekalipun, tidak niscaya arbitrer memang telah disinggung juga secara sekilas oleh Saussure di dalam bukunya (Saussure, 1966, p. 70) namun Peire-lah sebetulnya yang lebih banyak menaruh perhatian terhadap masalah ikonisitas (iconicity) ini. Menurut Marianto (Marianto, 2006, pp. 134-135) semiotika adalah kajian perihal tanda-tanda (signs), sistem tanda, dan cara bagaimana suatu makna ditarik dari tandatanda itu. Tanda adalah apa saja yang dapat dipakai untuk mewakili sesuatu yang lain, misalnya tanda? di badara udara yang berati tempat orang bertanya/ mencari informasi mengenai sesuatu. Tanda $\mathrm{Y}$ atau \$ disuatu sentra bisnis menandakan tempat penukaran mata uang asing.

Landasan penciptaan seni yang dikemukakan oleh Langer dalam Kartika (2004:2) yang mengemukakan bahwa seni merupakan kreasi bentuk simbolis dari perasaan manusia. Bentukbentuk simbolis yang mengalami transformasi yang merupakan universalisasi dari pengalaman, dan bukan terjemahan dari pengalaman tertentu dalam karya seninya, melainkan formasi pengalaman emosionalnya yang bukan dari pikiran semata.

Pendapat lainnya tentang seni menurut Gie (The Liang Gie, 1996, p. 60) kemahiran, kegiatan manusia, karya seni, seni indah, dan seni penglihatan (seni rupa). Sedangkan Hospers (Hospers, 1967, p. 1) menyatakan "dalam arti yang terluas, seni meliputi setiap benda yang dibikin oleh manusia sebagaimana dilawankan dengan bendabenda dari alam."
Menurut Couto (Couto \& Minarsih, 2009, p. 82) Seni rupa adalah media dimana seniman dapat mengekspresikan fantasi paling dalam dari dirinya. Menurut Setianingsih (2003:5) Seni rupa adalah segala manifestasi batin dan pengalaman estetis dengan media garis, bidang, warna, tekstur, volume, dan gelap terang.

Berdasarkan pendapat diatas dapat disimpulkan, seni rupa adalah seni yang memiliki wujud atau rupa yang diamati dengan panca indra yang merupakan manifestasi batin dari seniman, dengan menggunakan unsur-unsur seni rupa untuk menghasilkan benda-benda yang memiliki nilai estetis, kreatif, inovatif, dan mengesankan.

Setiap karya atau produk yang diciptakan seseorang tidak terlepas dari adanya unsur-unsur seni rupa. Dengan adanya unsur-unsur yang baik, suatu karya atau produk akan menjadi lebih baik pula. Sebelum membahas unsur-unsur yang ada pada karya seni lukis, ada baiknya diawali dengan memahami pengertian unsur-unsur itu sendiri.

Garis merupakan hal yang paling mendasar dalam sebuah karya seni. Tanpa garis, seorang seniman tidak akan bisa membuat bentuk yang diinginkan. Dharsono (2004: 40), mendefinisikan garis sebagai pertemuan dua titik yang saling dihubungkan. Sedangkan menurut Sidik dan Aming Prajitno (Sidik \& Prajitno, 1981, p. 4), garis didefinisikan sebagai (1) suatu goresan dan(2) batas limit dari suatu benda, massa, ruang, warna, dan lain-lain. Susanto (Susanto, 2011, p. 433) mendefinisikan warna sebagai getaran atau gelombang yang diterima oleh indera penglihatanmanusia yang berasal dari pancaran cahaya melalui sebuah benda.Cahaya yang dihasilkan dari penguraian melalui prisma kacamenghasilkan warna cahaya. Warna erbagi menjadi beberapabagian, yaitu warna primer, sekunder, intermediet, tersier dankuarter.

Tekstur juga tidak kalah penting peranannya dalam suatu karya seni lukis. Tekstur dapat menghadirkan kesan nyata maupun kesan semu dalam karya seni dan tentu sangat membantu seorang seniman dalam menyampaikan idenya. Definisi mengenai tekstur dijelaskan lebih dalam oleh Sidik dan Aming Prajitno (Sidik \& Prajitno, 1981, p. 41) sebagai tekstur merupakan nilai raba pada suatu permukaan baik nyatamaupun semu. Permukaan sendiri ada bermacam-macam, ada kasar dan halus, keras dan lunak, ada juga kesat dan licin. Tekstur sendiri terdiri dari dua macam yaitu tekstur nyata dan tekstur semu. Tekstur nyata merupakan tekstur yang dapat diraba secara fisik dan berbeda sifatnya, misalkan tekstur amplas akan berbeda jauh dengan tekstur kaca. Sedangkan tekstur semu merupakan tekstur yang dibuat berdasarkan ilusi mata dan jika diraba hasilnya sama saja. Tekstur sendiri memiliki kualitas plastis yang menimbulkan bayang-bayang pada 
permukaannya. Oleh karena itu, tiap benda yang berbeda permukaannya mempunyai sifat atau karakternya masing-masing.

Dharsono (Dharsono, 2007, p. 53) mendefinisikan ruang sebagai wujud trimatra atau tiga dimensi yang mempunyai panjang, lebar dan tinggi. Sedangkan menurut Djelantik (Djelantik, 1999, p. 24), ruang merupakan kumpulan dari beberapa bidang.

Dharsono (2007: 41) mendefinisikan shape atau bidang sebagai sebuah bidang kecil yang terjadi akibat adanya batas kontur (garis) dan atau batas warna yang berbeda atau karena adanya gelap terang atau adanya tekstur. Dalam menciptakan bentuk, perupa memilih prinsip-prinsip rupa, memadukan dan menyusunnya agar diperoleh bentuk yang menarik, memuaskan, atau membangkitkan pengalaman visual tertentu.

Menurut Kartika, (Kartika, 2004, p. 58) kesatuan merupakan efek yang dicapai dalam suatu susunan atau komposisi diantara hubungan unsur pendukung karya, sehingga secara keseluruhan menampilkan kesan tanggapan secara utuh.

Menurut Susanto, (Susanto, 2011, p. 46) keseimbangan atau balance adalah persesuaian materi-materi dari ukuran berat dan memberi tekanan pada stabilitas suatu komposisi karya seni

Menurut Kartika (Kartika, 2004, p. 48), harmoni atau selaras merupakan unsur-unsur yang berbeda dekat. Jika unsur-unsur estetika dipadukan secara berdampingan maka akan timbul kombinasi tertentu dan timbul keselarasan. Sedangkan menurut Kartika (Kartika, 2004, p. 63) aksentuasi merupakan susunan beberapa unsur seni rupa atau penggunaan ruang dan cahaya bias menghasilkan titik perhatian pada fokus tertentu.

Susanto (Susanto, 2011, p. 334) menjelaskan irama atau ritme. Irama dalam seni rupa menyangkut persoalan warna, komposisi, garis, maupun yang lainnya.

Menurut Kartika (Kartika, 2004, p. 54) merupakan perpaduan unsur-unsur yang berbeda tajam. Kontras merupakan hal penting dalam komposisi untuk pencapaian bentuk yang sesuai. Tetapi perlu diingat bahwa sebuah penyusunan kontras yang berlebihan akan merusak komposisi sebuah karya.

Menurut Kartika (Kartika, 2004, p. 55) gradasi merupakan suatu sistem perpaduan dari laras menuju kontras, dengan meningkatkan masa dari unsur yang dihadirkan. Gradasi merupakan perpaduan dari interval besar yang dilakukan dengan penambahan atau pengurangan secara bertahap. Seni lukis merupakan bahagian karya seni rupa yang umumnya termasuk yang paling tua, terbukti dengan ditemukannya lukisan peninggalan manusia zaman purba, di goa Prancis. Di Indonesia juga ditemukan lukisan telapak tangan seperti di goa layang-layang Sulawesi.
Pengertian seni lukis menurut Sahman (Sahman, 1993, p. 55) adalah proses membubuhkan cat, baik itu kental maupun cair di atas permukaan datar yang ketebalannya tidak diperhitungkan, sehingga lukisan tersebut sering dilihat sebagai karya dua dimensi. Seni lukis dapat dikatakan sebagai suatu ungkapan pengalaman estetik seseorang yang dituangkan dalam bidang dua dimensi (dua matra), dengan menggunakan medium rupa, garis, warna, tekstur, shape, dan sebagainya Kartika, (Kartika, 2004, p. 36)

Susanto (Susanto, 2011, p. 364) mendefinisikan simbol sebagai suatu bentuk tanda yang semu natural, yang tidak sepenuhnya terbentuk begitu saja. Simbol harus berdasarkan pada konvensi dan satu aspek dari sebuah simbol tidak menghindari aspek-aspek lainnya. Sedangkan Djelantik (Djelantik, 1999, p. 182) mengartikan simbol sebagai suatu tanda (rambu, lukisan, perkataan, lencana, dan sebagainya) yang menyatakan suatu hal atau mengandung maksud tertentu. Penjelasan mengenai metafora dijelaskan oleh Susanto (2011: 258) sebagai suatu istilah yang biasa dipakai untuk mengacu pada pergantian sebuah kata yang harfiah dengan sebuah kata lain yang figuratif. Mereka memiliki kemiripan atau analogi di antara kata yang harfiah. Metafora dapat berupa perlambangan dan bahasa tanda yang dapat mewakili pikiran pemakainya dalam menumpahkan gagasangagasannya. Setiap perupa biasanya memiliki metafora, seperti Affandi dengan ayam mati, potret diri atau kapal-kapalnya, Dadang Christanto dengan manusia tanahnya, S. Sudjojono dengan wanita-wanita misterinya, atau Iwan Sagito dengan sapi-sapinya, dan lain-lain.

Menurut Margono, (Margono Dkk, 2006, p. 6)) munculnya karya seni rupa kontemporer adalah karya seni yang lebih banyak dipengaruhi oleh waktu sehingga situasi dan kondisi ketika karya ini dibuat terasa mewakili karya kontemporer. Ide atau gagasan ini muncul untuk menanggapi sesuatu yang terjadi. Tanggapan berupa kritik, saran, pesan, berontak, ataupun sekedar merekam yang terjadi di lingkungannya tersebut di tuangkan ke dalam sebuah karya seni melalui lukisan, patung, seni grafis, dan seni instalasi.

Menurut Saidi (Saidi, 2008, p. 8), kata "kontemporer" yang diletakkan pada frasa "seni rupa" bukan merupakan istilah yang merujuk pada sebuah aliran atau gaya berkesenian, melainkan hanya sebuah aktivitas berkesenian yang dianggap terkini pada setiap setiap zaman oleh pengamat yang hidup pada setiap zaman yang bersangkutan.

\section{PEMBAHASAN}

\section{Konsep Penciptaan}

Konsep perwujudan karya seni tidak terlepas dari bagaimana mengekspresikan suatu objek yang 
akan diciptakan dengan memperhitungkan nilai estetis dan kreatif. Konsep penciptaan lukisan menggunakan bahasa simbolik dan metafora dengan penggambaran objek payung yang menggambarkan pemimpin. Objek payung, dalam penciptaan lukisan dipertahankan karena penulis ingin menggunakan bentuk representasional payung dalam mengekspresikan ide atau gagasan. Dalam mewujudkan ide mengenai pemimpin dalam bentuk payung, penulis mempunyai konsep perujudan dengan berbagai jenis dan model payung , serta metafor yang mengutamaakan makna yang ingin penulis sampaikan. Dalam proses pembuatan karya akhir ini penulis mengeksporasi rasa-rasa yang ada dalam diri penulis selama ini ke dalam karya lukis sekaligus sebagai bentuk respon dari keadaan yang terjadi di sekitar diri penulis.

\section{Proses Penciptaan}

Perwujudan ide-ide seni, penulis melakukan beberapa tahap diantaranya tahap persiapan, tahap elaborasi, tahap sintesis, tahap realisasi konsep dan tahap penyelesaian. Pada tahap persiapan, penulis melakukan pengamatan terkait dengan tema yang penulis angkat, mencari dan menelaah masalahmasalah yang berkaitan tentang kepemimpinan. Kemudian pada tahap elaborasi, penulis melakukan pendalaman mengenai pemimpin dengan menganalisis masalah-masalah yang berkaitan dengan pemerintahan, seperti hal umum yang berubungan dengan pemerintah, baik sikap dan tindakan dalam menjadi pemimpin. masuk kepada sintesis yaitu tahap pembuatan konsep karya. Ketika konsep karya sudah tercipta, masuk kepada realisasi konsep yaitu menciptakan karya dua dimensi yaitunya lukisan bercorak realis kotemporer. Sebelum menuangkan ke bidang kanvas terlebih dahulu melakukan seleksi sketsa dan terakhir adalah tahap penyelesaian, pada tahap ini penulis melakukan finishing karya, persiapan pameran seperti pembuatan catalog sampai kepada pameran karya akhir.

\section{Deskripsi Penciptaan}

Keindahan dalam karya seni lukis tercipta melalui proses yang sangat panjang, mulai dari pencarian masalah tentang tema dan judul yang diangkat, pengamatan tentang pemimpin, dan bagaimana cara menvisualisasikan ke dalam bentuk karya seni lukis. pada saat ini pemimpin menjadi pandangan negatif di masyarakat umun dan orang yang menjadi pemimpin sering telibat kasus kriminalitas dan korupsi, sehingga masalah tersebut dianggap sebagai virus dalam kepemimpinan, itu terbukti bahwa yang melekukan tindakan kejahatan misalnya pemerkosaan, korupsi, pemakai narkoba, penipuan dan pelecehan agama islam. Enam karya yang dihasilkan dalam proses penciptaan dibahas dan dideskripsikan satu per satu.

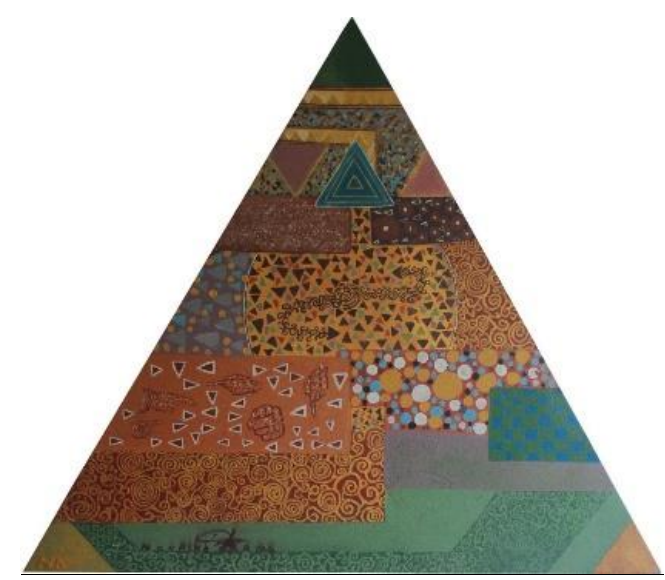

Gambar 1. Time is Reversed

Acrylic on canvas, ukuran 100x100 tahun 2017

Pada karya pertama ini adalah bentuk segitiga yang mana di karya ini terdapat bentuk dekoratif yang terdiri dari susunan bidang-bidang. Warna-warna yang digunakan kebanyakan warna hijau, emas, biru, coklat, orange dan ungu. Dalam karya ini terdapat juga bentuk tanggan yang menunjuk dan di tenggah terdapat bentuk lingkaran seperti jam. Jarum jam disini berarti berbalik arah.

Dalam karya ini terdapat warna hijau sebagai metafor sawah. Lingkaran yang berputar symbol kehidupan. Kemudian lingkaran adalah sikap atau kepercayan masyarakat yang mulai berkurang terhadap seorang pemimpin dalam suatu intansi pemerintah.Bentuk segitiga dalam karya ini membahas tentang hukum yang tidak seimbang lagi.

Karya ini menjelaskan sebuah prosedur dalam mengurus masalah-masalah masyarakat sehari-hari yang di perlambat oleh seorang pemimpin dalam sebuah instansi pemerintah. Seperti dalam pengurusan surat tanah dan lain-lain. Rakyat seperti dipermainkan menunggu lama namun asilnya tidak ada. Namun ketika yang mengurus adalah seorang pejabat proses yang lambat menjadi cepat.

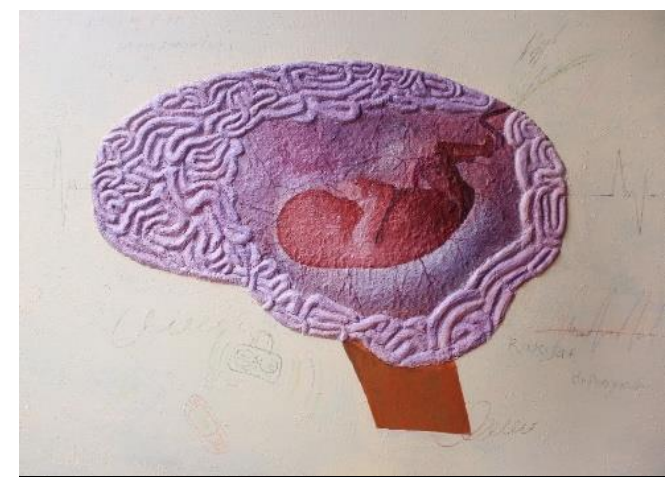

Gambar 2. The Doctrine of the Leader Acrylic, bubuk kertas on canvas, 
ukuran 100x130 tahun 2017

Pada karya kedua ini adalah bentuk otak dan janin yang berada dalam otak. Pada karya ini sudah mulai di tonjolkan seperti relif. Karya ini terdapat bermacam coretan yang menjadi Bahasa ungkap dalam karya ini. Warna dalam karya ini terdiri dari warna soft. Karya ini memperlihatkan objek otak dan janin yang digabungkan dalam satu bentuk. Seperti kita tau otak adalah pusat kendali pikiran manusia, sedangkan janin adalah sebuah proses pertumbuhaan manusia.

Teknik yang digunakan yaitu bubuk kertas yang direkatkan ke kanvas dengan mengunakan lem Fox. Setelah itu dilapisi dengan cat agar menjadi menarik. Dalam karya ini saya mengunaakan krayon untuk membuat objek pendukung dalam karya dan coretan sebagai estetika.

Karya ini membahas masalah doktrin seorang pemimpin dalam pemeritahan untuk memaksakan kehendaknya dan mempengaruhi pikiran rakyat dengan janji serta kata-katanya. Dalam karya ini terdapat coretan dan gambar yang menjelaskan sesuatu yang menjadi proses doktrin itu sendiri. Seperti media sosial baik itu melalui Televisi, Radio dan Surat kabat. Semua itu adalah proses seorang pemimpin untuk mempengaruhi pemikiran rakyatnya.

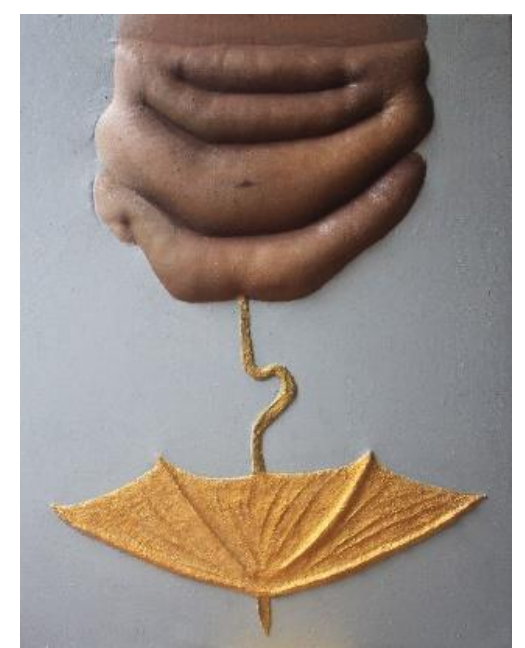

Gambar 3. No Longer Body Size

Acrylic, bubuk kertas, dakron on canvas ukuran $100 \times 50$ tahun 2017

Pada karya ketiga ini adalah bentuk sebuah perud yang melebihi batas dari yang dikosumsinya. Kita juga dapat melihat bentuk payung dalam karya ini yang mana payungnya bengkok di bagian tengah karena menompang beratnya kapasitas yang menjadi bebanya. Warna yang digunakan pada karya ini adalah warna abu-abu, emas, kuning dan coklat.

Pada karya ini mulai mengunakan Teknik yang berbeda dari karya sebelumnya, yaitu bentuk objek utama sudah di timbulkan dengan menyatukan bagian kanvas. Disini saya mengunakan sketsa di kain kanvas kemudian di jahit dan di isi dakron untuk menimbulkan kesan perud dalam karya ini. Tidak hanya itu, saya juga mengunakan serbuk kertas untuk membentuk objek paying yang di tempel-tempelkan.

Karya ini membahas tentang seorang pemimpin yang banyak melakukan tindakan yang menyimpang dan mencurangi rakyat. Pemimpin disini ingin memperkaya diri sendiri dengan mengambil hak-hak rakyat. Seperti korupsi yang sering menjadi makanan sehari-hari para pemimpin yang melakukan kecurangan dalam kepemimpinanya. Sehingga payung disini sebagai metafor seorang pemimpin yang sudah rusak.

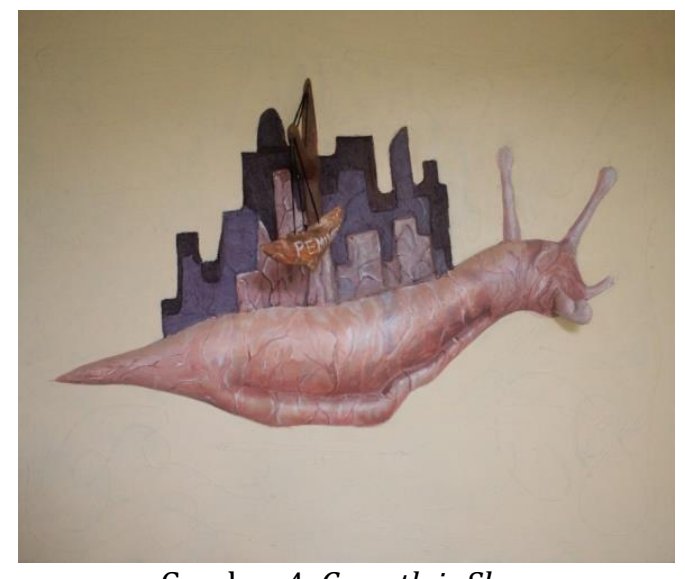

Gambar 4. Growth is Slow

Acrylic, bubuk kertas, dakron on canvas ukuran 100x120 tahun 2017

Pada karya keempat ini adalah bentuk sekor siput yang membawa sebuah bagunan. Bagunan pada karya ini dapat kita amati terdapat warna berbeda masing-masinya dan ada beban yang di angkut oleh bagunan itu sendiri. Warna yang digunakan pada karya ini adalah warna kuning, ungu, coklat, biru orange dan putih.

Tekinik dalam karya ini masih mengunakan Embos dengan Teknik jahit dan serbuk kertas. Pada karya ini saya mulai melihatkan benang dalam karya pada bentuk jangkar itu sendiri. Bentuk siput masih menggunak dakron untuk menonjolkan objek tama kemudian di jahit.

Karya ini membahas masalah sebuah pembangunan yang lambat seperti sekor siput yang lambat, namun siput sering di gunakan untuk produk obat kecantikan, sama halnya dengan janji seorang pemimpin ketika memjanjikan sebuah pembagunan ini dan itu ketika dia terpilih menjadi seperti obat untuk rakyat. Orang berbondong ingin menjadi pemimpin dan rame menjanjikan ini itu ketika pemilihan, namun ketika dia terpilih dia lupa dengan janjinya itu sendiri. 


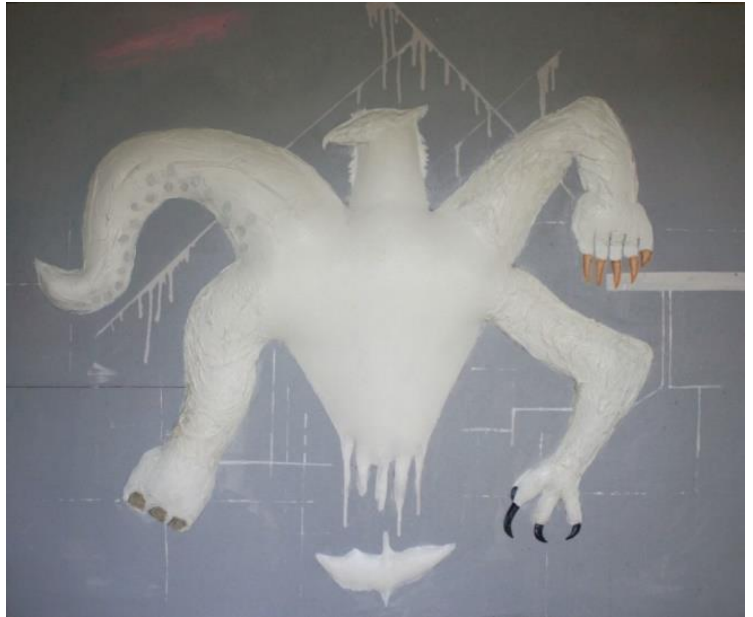

Gambar 5. Krakter Pemimpin

Acrylic, dakron dan kertas on canvas

ukuran 100x120 tahun 2017

Pada karya kelima ini adalah bentung bagian dari tubuh binatang, dapat kita amati terdapat bentuk kaki Burung Elang, kaki Harimau, kaki Gajah, tentakel Gurita dan kepala burung Garuda. Pada karya ini terdapat bentuk segitiga yang meleleh yang menjadi pusat dari setiap bagian tubuh binatang itu sendiri. Payung sebagai penampung lelehan dari segitiga yang meleleh. Warna yang condong digunakan pada karya ini adalah Abu-abu, Putih dan ping. Kita juga dapat melihat sebuah garis yang meleleh dan putus-putus, serta kesan ping di sebagian bidang kanvas.

Dalam karya ini masih mengunakan Teknik yang sama tapi sudah tidak memakai bubuk kertas lagi. Pada karya ini saya mengunakan kertas telo untuk membentuk kerutan dalam bentuk-bentuk kaki dan kepala binatang. Disini saya sedikit mengunakan cat untuk menimbulkan kesan-kesan dari jenis binatang dalam objek karya ini.

Karya ini membahas masalah prilaku seorang pemimpin yang tidak mau mengakui kesalahanya sendiri. Pada karya ini saya lebih banyak mengunakan Bahasa metafor di setiap bagian objek karya ini. Seperti bentuk segitiga yang meleleh menjelaskan hukum yang mulai melemah. Kaki binatang mewakili sifat-sifat istimewa binatang. Ketika seseorang pemimpin ketauan korupsi dia mengelak, seperti harimau yang lincah. Ketika dia terjepit dalam kasus hukum dia berusaha mencari selah untuk membenarkan dirinya, seperti halnya gurita yang licin. Ketika yang terkena masalah hukum adalah seorang pemimpin yang berkuasa maka hukum terasa lambat. Seperti gajah yang memiliki kekuatan yang kuat dan pendengaran yang mampu mendeteksi suara walapun jaraknya jauh sekalipun.

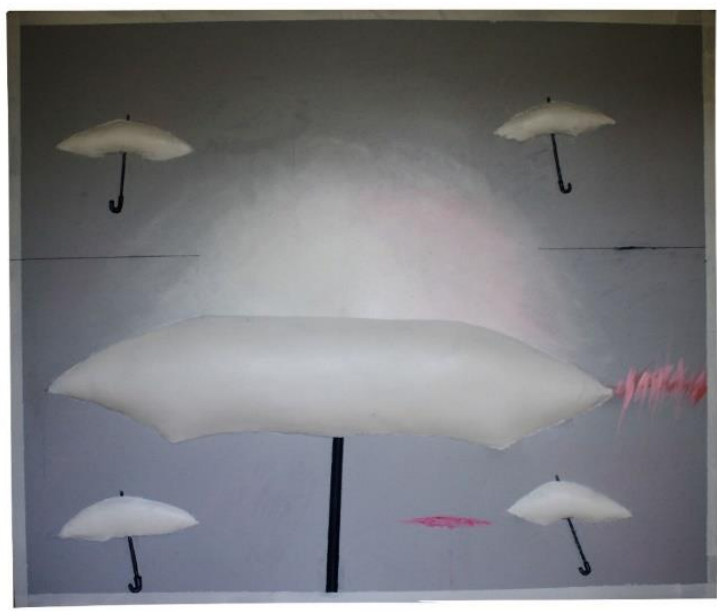

Gambar 6. Kong kali kong

Acrylic, dakron on canvas

ukuran 100x120 tahun 2017

Pada karya keenam ini adalah bentuk payung yang terdiri dari lima payung dari objek payung yang kecil. Kemudian terdapat empat payung dan satu payung besar. Masing-masing empat payung mengadap kearah kiri dan salah satu payung menghadap kekanan. Pada karya ini terdapat garis lurus yang hilang ketika beraba ditengah. Dalam karya ini juga terdapat goresan spontan.

Warna yang digunakan kebanyakan warna Abu-abu, putih dan ping. Teknik yang digunakan masih Teknik yang sama yaitu menjahit dan mengisi dakron kemudia melapisi dengan cat putih. Pada teknik ini tidak mengunakan kertas maupun bubuk kertas, melaikan jahitan yang di isi dakron. Karya ini masih membahas tentang kepemimpinan. Payung besar sebagai metafor seorang yang ingin menjadi pemimpin dan payung kecil sebagai sekong-kolanya untuk mendapatkan posisi kepemimpinan dengan mengunakan orang dalam yang juga mempunyai kekuasan dalam bidang tertentu untuk menaikanya ke posisi teratas. Segala cara digunakan untuk mencapai posisi teratas itu dengan persekongkolan antara pemimpin.

\section{KESIMPULAN}

Pada kenyataannya dunia seni itu memiliki peranan yang sanggat penting dalam kehidupan bermasyarakat. Seni memiliki peranan penting untuk kehidupan secara personal bahkan untuk dunia seni itu sendiri. Tanpa adanya seni, segala sesuatu yang dihadirkan di muka bumi akan terlihat hampa, suram dan jelas tidak menarik. Namun dengan adanya seni kehidupan akan terasa lebih menyenangkan dan bergairah. Seni selain menampilkan hal-hal yang dianggap memiliki nilai estetika juga mampu menjadi media dalam penyampaian rasa atau sebagai ungkapan ekspresi dari perasaan ataupun imajinasi seseorang. 
Seiring dengan bertambah banyaknya problematika dalam kehidupan yang dikarenakan oleh berbagai faktor dalam hidup, seperti permasalahan pekerjaan, tuntutan hidup, gaya hidup, dan lagi perkembangan dunia yang semakin pesat. Penulis juga memberikan saran kepada semua masyarakat berhati-hatilah dalam memilih pemimpin, dimana Indonesia sudah sangat terpengaruh oleh pemimpin yang berjanji manis dan sebagian pemimpin terjebak koropsi dan kriminalitas.

\section{UCAPAN TERIMA KASIH}

Syukur Alhamdulillah senantiasa saya Ucapkan kehadirat Allah SWT. yang memiliki keistimewaan dan pemberian segala kenikmatan besar, baik nikmat iman, kesehatan dan kekuatan didalam penyusunan Paper ini. Salawat dan salam senantiasa tercurahkan kepada Sayyidina Muhammad SAW. Selanjutnya tidak lupa ucapan terimakasih kepada semua pihak yang telah membantu dalam penyelesaian makalah ini, antara lain: Sahabat seni rupa dan rekan-rekan yang selalu setia menemani penulis memberikan semangat setiap harinya dan semua pihak yang tidak bisa penulis sebutkan satu persatu, namun telah sangat membantu dalam penyelesaian makalah ini baik itu memberikan masalah dalam hidup penulis ataupun masukan berharga dalam setiap permasalahan yang penulis hadapi. Semoga makalah ini dapat memberikan manfaat untuk setiap masyarakat, kritik dan saran dari pembaca sangat penulis harapkan untuk kelengkapan dan kesempurnaan makalah ini.

\section{DAFTAR PUSTAKA}

Anggia, D., \& Fredy. (2006). Penemuan Payung. Jakarta: PT. Elex Media Komputindo Gramedia.

Budiman, K. (2011). Semiotika Visual. Yogyakarta: Jalasutra.

Couto, N., \& Minarsih. (2009). Seni Rupa Teori dan Aplikasi. Padang: Universitas Negeri Padang Press.

Dharsono. (2007). Kritik Seni. Bandung: Rekayasa Sains.

Djelantik. (1999). Estetika Sebuah Pengantar. Bandung: Masyarakat Seni Pertunjukan.

Hospers, J. (1967). The Ency Lopedia Of Philosophy. Yogyakarta: Pustaka Bersama.

Kartika, D. S. (2004). Seni Rupa Modern. Bandung: Rekayasa Sains.

Margono Dkk. (2006). Apresiasi Seni Seni Rupa dan Seni Teater 3 SMA Kelas XII (bahan ajar). Jakarta: Yudhistira.

Marianto, M. D. (2006). Quantum Seni. Semarang: Dhara Prize.

Sahman, H. (1993). Mengenali Dunia Seni Rupa. Semarang: IKIP Semarang Press.

Saidi, A. I. (2008). Narasi Simbolik Seni Rupa Kontemporer Indonesia. Yogyakarta: Isacbook.

Saussure, F. de. (1966). Course in General Linguistics. New York: McGraw Hill.

Sidik, F., \& Prajitno, A. (1981). Desain Elementer. Yogyakarta: ASRI.

Susanto, M. (2011). Diksi Rupa, kumpulan dan istilah seni rupa. Yogyakarta: Dicti Art Lab \& Djagad Art House.

Taniredja, T. (2014). Pemimpin Berkarakter Pancasila. Bandung: Alfabeta.

The Liang Gie. (1996). Filsafat Seni Sebuah Pengantar. Yogyakarta: Pusat Belajar Ilmu Berguna (PUBIB). 
Novriko Darma / IKONIK : Jurnal Seni dan Desain, Vol. 1, No.1, Juli 2019, 61-68

(Halaman ini sengaja dikosongkan) 